\section{Next-generation synchrotron to be built in Berlin?}

\section{West Berlin}

DETERMINED not to fall behind in the race to build the next generation of synchrotron radiation sources, the West German government seems likely to approve a new 1.5 GeV storage ring in West Berlin. BESSY II (for Berliner Elektronenspeicherring-Gesellschaft für Synchrotronstrahlung) will have eight 'wigglers', essentially regions of corrugated magnetic field, to concentrate photon production in particular parts of the ring. This technique is also being used in synchrotrons in the same energy range in Italy, France and the United States.

BESSY II would build on its predecessor, BESSY I, a vacuum storage ring operating in West Berlin since 1982. By building BESSY II, West Germany could stay abreast of the Italian synchrotron planned for Trieste and the Advanced Light Source at Berkeley in the United States. None of these synchrotrons will approach the particle energies (up to 5 GeV) achieved by the European Synchrotron Radiation Facility under construction at Grenoble. BESSY II will cost roughly DM 80 million and the storage ring could go on-line by 1991 .

Once built, BESSY II would be turned over to a private corporation, following the precedent of BESSY I, which is jointly owned by the Max Planck Society, the Fraunhofer Society, the Hahn-Meitner Institute of West Berlin, DESY (the Deutsches Elektron Synchrotron) as well as by Siemens, AEG, Philips and Eurosil.

The location of a successor to BESSY I will depend in part on which way the political winds are blowing. West Berlin depends on West Germany for large-scale financial support and there has lately been talk that the city might lose some of its DM 800 million subsidy when the West German tax reform package comes into effect in 1990. A decision is expected by autumn 1988.

Support from potential users of BESSY II may help to tip the scales in its favour. According to Heinz Lindenberger, director of the Hahn-Meitner Institute, "the customers are queuing up already". A group at the University of Göttingen would use the new synchrotron to do realtime X-ray microscopy. The Nuclear Research Institute at Jülich would perform spin-polarized photoemission spectroscopy, and a group from the Fritz Haber Institute is interested in studying catalysis.

Steven Dickman

\section{IMAGE UNAVAILABLE FOR COPYRIGHT REASONS}

\section{UK compensates AIDS haemophiliacs}

\section{London}

HAEMOPHILIACS who have become infected with the AIDS virus through contaminated blood products prescribed on the National Health Service are to benefit from a $£ 10$ million compensaton fund to be announced by Mr John Moore, the Social Services Secretary, this week.

The biggest payments will go to the 21 haemophiliacs already suffering from the full-blown disease. Families of the $\mathbf{4 5}$ who have already died will also be compensated. There are currently 1,200 infected haemophiliacs in Britain.

The government is expected to insist that the fund does not represent compensation to avoid setting a precedent for special benefit schemes. A spokesman for the
Department of Health and Social Security (DHSS) said: "It is not compensation. The Haemophilia Society will have the money and will deal with it themselves". They are also unwilling to do anything that could be taken as an admission that supplies of the blood-clotting agent, factor VIII, were not safeguarded against contamination when the threat of AIDS was identified 4 years ago.

Last month the DHSS said that if haemophiliacs wanted compensation they would have to sue for negligence. Some patients are planning such action. But Moore appears to have convinced the government that the problems of haemophiliacs suffering from AIDS are exceptional.

\section{Lysenkoism still holding sway}

\section{London}

THE Soviet popular-science monthly, Priroda (Nature) last month devoted an entire issue to the life and works of Nikolai Vavilov, in celebration of the centenary of his birth. Although, in the course of its 75 years' existence, Priroda has frequently celebrated the anniversaries of significant scientists and events, a single-theme issue of this kind is unusual - so all the more significant.

Vavilov was not only one of the Soviet Union's leading biologists and geneticists of the $1920 \mathrm{~s}$ and $1930 \mathrm{~s}$, but also the most eminent victim of lysenkoism. Although he has long since been posthumously rehabilitated, this special issue has given Priroda an excellent opportunity to exhibit glasnost (openness) by revealing such hitherto unknown events and material as Vavilov's campaign to protect his genetics institute in 1938 and the drafts of research programmes and plans that he was prevented, by political pressures, from carrying out.

But the commemorative issue contains a warning that the fight against lysenkoism is not yet over. Among the book reviews is an attack on a series of pamphlets aimed, the reviewers claim, at rehabilitating if not Lysenko himself, then at least some of the leading figures of the Lysenko period, including, first and foremost, Michurin. One of these brochures "Michurin and Contemporary Biology", the reviewers note, actually credits Michurin with the formulation of five scientific laws, although Michurin (primarily a practical man) never made any such claim. The authors of the brochures, B.G. Ioganzen of Tomsk State University and E.D. Logachev, of Lemerovo State Medical Institute, have, said the reviewers, taken advantage of glasnost to issue works which are "dangerous" and liable to "disorientate the insufficiently informed reader", and to lead to opinions which are both philosophically unsound and harmful for agricultural and medical practice". They also attempt to discredit genetics by suggesting that it can lead to such unacceptable consequences as "socialdarwinism, eugenics and racism". In the face of such "distortions" and "sophistry", the reviewers claim in their title, "we cannot keep silent".

It is "not by chance", the reviewers stress, that they have placed their warning in the Vavilov memorial number of Priroda. The prestige of the journal and the occasion, they hope, will help alert the Soviet ministries of Higher Education and of Health, as well as "wide circles of the scientific community" to the danger of a lysenkoist revival.
Vera Rich 